\title{
Effect of Post-Mating Treatment with Controlled Internal Drug Release (CIDR) on Pregnancy Rate of Repeat Breeder Egyptian
} Buffaloes

\section{Mohamed Abd El-Fattah Abo-Farw ${ }^{1}$, Wael Mohamed Nagy ${ }^{1}$, Abdel-Khalek El-Sayed AbDEL-KhaleK ${ }^{*}$ \\ ${ }^{1}$ Animal Production Research Institute, Agricultural Research Center, Egypt; ${ }^{2}$ Department of Animal Production, Faculty of Agriculture, Mansoura University, Egypt.}

\begin{abstract}
To reduce early embryonic loss and improving pregnancy rate (PR) of Egyptian repeat breeder buffaloes, 45 repeat breeder animals were used in this study. Buffalo cows $(n=30)$ and buffalo heifers $(n=15)$ were allocated to three groups (10 cows and 5 heifers in each). Animals exhibiting normal heat were naturally mated. On Day 5 post-mating, a Controlled Internal Drug Release (CIDR-B) device was inserted on Day 5-9 (Protocol 1, P1), and Day 5-18 (Proto$\mathrm{col} 2$, P2) post-mating. Animals in the $3^{\text {rd }}$ group (Control) were left without treatment. Blood samples were taken on different days post- mating. Results show overall pregnancy rate (PR) of 46.7, 66.7 and $13.3 \%$ in P1, P2 and control $(\mathrm{P}<0.05)$, being higher in buffalo-cows than in buffalo-heifers (46.7 vs. 33.3\%, $\mathrm{P}<0.05)$. In controls, $\mathrm{PR}$ was 0 in buffalo-heifers and $20 \%$ in buffalo-cows. Level of progesterone $\left(\mathrm{P}_{4}\right)$ was higher $(\mathrm{P}<0.05)$ in $\mathrm{P} 1$ and $\mathrm{P} 2$ than in control on most post-mating days following CIDR insertion, being higher in $\mathrm{P} 2$ than in $\mathrm{P} 1$, and higher $(\mathrm{P} \geq 0.05)$ in cows than in heifers. Level of $\mathrm{P}_{4}$ at estrus decreased $(\mathrm{P}<0.01)$, while post-mating $\mathrm{P}_{4}$ levels increased for all pregnant in comparing with non-pregnant animals. In conclusion, increasing the progesterone concentrations by CIDR treatment from 5-18 days post-mating could be a useful strategy to prevent or reduce embryo mortality and is recommended for improving pregnancy in repeat breeder buffalo cows and heifers.
\end{abstract}

Keywords | Buffalo, Repeat breeder, Estrus, Progesterone, Pregnancy

Received | June 01, 2021; Accepted | June 24, 2021; Published | November 15, 2021

*Correspondence | Abdel-Khalek El-Sayed Abdel-Khalek, Department of Animal Production, Faculty of Agriculture, Mansoura University, Egypt; Email: abdelkhalk2004@yahoo.com

Citation | Abo-Farw MA, Nagy WM, Abdel-Khalek AE (2021). Effect of post-mating treatment with controlled internal drug release (cidr) on pregnancy rate of repeat breeder egyptian buffaloes. J. Anim. Health Prod. 9(4): 504-511.

DOI | http://dx.doi.org/10.17582/journal.jahp/2021/9.4.504.511

ISSN | 2308-2801

Copyright $(0) 2021$ Abdel-Khalek et al. This is an open access article distributed under the Creative Commons Attribution License, which permits unrestricted use, distribution, and reproduction in any medium, provided the original work is properly cited.

\section{INTRODUCTION}

$\mathrm{L}$ ow reproductive efficiency and longer calving interval are the major problems faced by buffalo breeders and farmers (Singh et al., 2000). In farm animals, the culling rate of repeat breeder animals causes economic losses, whereas it is an important disorder of animal reproduction. Repeat breeding was given in consideration when the female receive $\geq 3$ insemination without pregnancy, and their genital tracts without obvious pathological disorders (E1-Khadrawy et al., 2011). Disturbance in the hormonal balances and ovulation time, fertilization frailer, and early embryonic mortality are the main causes of repeat-breeding (Patel et al., 2014). In buffaloes, low conception rate in cows (Azawi et al., 2008) and heifers (Abo-Farw et al., 2009) is the main problem in the incidence of repeat breeding. Several attempts were carried out to reduce repeat breeding by administering hormone therapy to improve embryonic mortality (Singh et al., 2017). Some problems associated with repeat-breeders could be eliminated by the use of hormonal protocols designed to increase pregnancy rates (Rodrigues et al., 2010). In this respect, Abo-Farw et al. (2009) increase pregnancy rate of repeat breeder heifers to 70, 80 and $90 \%$ using GnRH- $\mathrm{PGF}_{2} \alpha-\mathrm{GnRH}$, 
$\mathrm{GnRH}$ at insemination and $\mathrm{PGF}_{2} \alpha-\mathrm{PGF}_{2} \alpha$ (11-day interval), respectively. Also, pre-synchronization of estrus and ovulation using controlled internal drug release (CIDR) and $\mathrm{PGF}_{2} \alpha$ achieved improvement in pregnancy rate from 20 to $60 \%$ in buffalo-cows and from 0 to $60 \%$ in buffalo-heifers (Abo-Farw et al., 2019). It was mentioned that embryonic loss may be, partially, attributed to a decrease in progesterone $\left(\mathrm{P}_{4}\right)$ secretion by corpus luteum (CL) during early pregnancy (Campanile et al., 2005) and elevated concentrations of circulating $\mathrm{P}_{4}$ are required for conceptus development in repeat breeding crossbred cattle (Savalia et al., 2014). More exposure to $\mathrm{P}_{4}$ by the embryo may increase its chance of secreting interferon- $t$ and thus survive (Thatcher et al., 2001).

Lonergan et al. (2013) reported positive impacts on fertility by supplementing additional $\mathrm{P}_{4}$. In buffaloes, $\mathrm{P}_{4}$ is important for incidence and maintenance of pregnancy, and increasing embryo implantation rate (Kastelic, 1994). Many authors (Walsh et al., 2007; Chebel et al., 2010) reported improved reproductive efficiency of cyclic cows following treatment with different $\mathrm{P}_{4}$ devices. In this respect, using CIDR could be applied to improve fertility in buffaloes (Singh, 2003a) and repeat breeder Iraqi buffaloes (Azawi et al., 2012).

Progesterone is essential for the maintenance of pregnancy (Karen et al., 2014). Lesser concentrations of $P_{4}$ may increase the risk of poor embryo quality after fertilization (Ahmad et al., 2004). Many methods have been tried to reduce embryonic mortality by enhancing endogenous $\mathrm{P}_{4}$ level as lower than the normal rise and lower total $\mathrm{P}_{4}$ concentration have been reported in repeat breeder cows (Gaja et al., 2008).

Based on the positive relationship between $\mathrm{P}_{4}$ post-insemination and the maintenance of pregnancy, the present study hypothesized that elevating post-mating period $\mathrm{P}_{4}$ level by CIDR may compromise conceptus development during pregnancy, which might increase the pregnancy rate in repeat-breeder buffaloes. So, the current study aimed to improve pregnancy rate by using CIDR at different intervals post-mating in repeat-breeder buffalo cows and buffalo heifers.

\section{MATERIALS AND METHODS}

This study was achieved by Animal Production Research Institute (APRI), Agricultural Research Center, Ministry of Agriculture, in cooperation with Animal Production Department, Mansoura University, Egypt. The experimental period lasted during the interval from May to September 2019. Animal Ethics Committee of Mansoura University, Egypt approved this study.
Animals

Total of 45 experimental animals with normal estrous cycles but failed to conceive after three successive services per animal (repeat breeder buffaloes) were taken from the herd of Mehallet Moussa Station of Animal Production, Kafrelsheikh Governorate, belonging to APRI. The experimental animals included 30 lactating Egyptian buffaloes three months in milk, weighing $450-500 \mathrm{~kg}$, aging 4-5 years, and within 2-3 parities were used. Also, fifteen cyclic Egyptian buffalo heifers weighing $350-400 \mathrm{~kg}$ and aging 2.5-3 years were used in this study. The experimental buffalo cows showed normal calving and had no clinical illness signs detectable during the previous seasons. The rectal palpation and ultrasonography examination revealed intact reproductive tract of all experimental animals. Animals were housed under semi-open sheds. All animals were managed at similar feeding and managerial conditions applied in Animal Production Research Institute. Animals were free and kept under semi-open sheds.

\section{FEEDING SYSTEM}

The experimental animals were reared under traditional feeding and management systems; they were fed on diet that cover both maintenance and milk production requirements for buffaloes and based on LBW of heifers according to the recommendation of APRI. The ration of the experimental animals included concentrate feed mixture, CFM (33\% un-decorticated cotton seed, 23\% yellow corn, $22.3 \%$ wheat bran, $13 \%$ rice bran, $2 \%$ molasses, $3 \%$ limestone, $1.2 \%$ common salt and $2.5 \%$ calcium), berseem hay $(\mathrm{BH})$, corn silage (CS), and rice straw (CS). Fresh water was available all times. Table 1 show the chemical composition (on dry matter basis) of concentrate feed mixture, berseem hay, corn silage and rice straw. The methods of AOAC (2000) were used to obtain the chemical analysis of representative samples taken from all feedstuffs.

\section{EXPERIMENTAL DESIGN}

At the beginning of the experiment, thirty buffalo cows and fifteen buffalo heifers were divided into 3 groups (ten cows and five heifers each) based on live weight and age. Animals were naturally mated after estrous detection of the experimental animals (every morning and evening by visual observation twice daily, 6 a.m. and 6 p.m. for at least 30 min by teaser bull. Buffalo cows and heifers in heat were naturally mated by fertile buffalo bull.

On Day 5 post-mating, a CIDR-B device containing $1.9 \mathrm{~g}$ of progesterone (Vetrepharm Canada Inc., Belleville, ON, Canada) was inserted in the vagina of each animal for 4 days in the $1^{\text {st }}$ group (Protocol 1, P1), and for 13 days in the $2^{\text {nd }}$ group (Protocol 2, P2). CIDR was withdrawal on Day 9 post-mating in the $1^{\text {st }}$ group and on Day 18 in the $2^{\text {nd }}$ group. Animals in the $3^{\text {rd }}$ group (Control) were left with 
Table 1: Chemical composition of different feedstuffs (on DM basis).

\begin{tabular}{|c|c|c|c|c|c|c|c|}
\hline \multirow[t]{2}{*}{ Feedstuff } & \multirow[t]{2}{*}{ DM \% } & \multicolumn{6}{|c|}{ Chemical composition on DM basis (\%) } \\
\hline & & OM & $\mathbf{C P}$ & CF & EE & NFE & ASH \\
\hline CFM & 90.31 & 89.70 & 16.44 & 12.79 & 4.24 & 56.23 & 10.30 \\
\hline $\mathrm{BH}$ & 88.52 & 88.45 & 15.32 & 23.43 & 5.14 & 44.56 & 11.55 \\
\hline CS & 38.14 & 91.40 & 10.94 & 18.84 & 4.33 & 57.29 & 8.60 \\
\hline RS & 91.02 & 83.06 & 2.70 & 36.93 & 1.53 & 41.90 & 16.94 \\
\hline
\end{tabular}

CFM: concentrate feed mixture, BH: berseem hay, CS: corn silage, RS: rice straw, DM: dry matter, OM: organic matter, CP: crude protein, CF: crude fiber, EE: ether extract, NFE: nitrogen free extract.

out treatment during the experimental period at similar time near to other treatments. Blood samples were taken on Days 0 (estrus incidence), 3, 6, 9, 12, 15, 18, 21 and 24 post- mating, from all animals in each group. Pregnancy was diagnosed on day 24 post-mating by ultrasonographic examination. The experimental designs summarized in Figure 1.

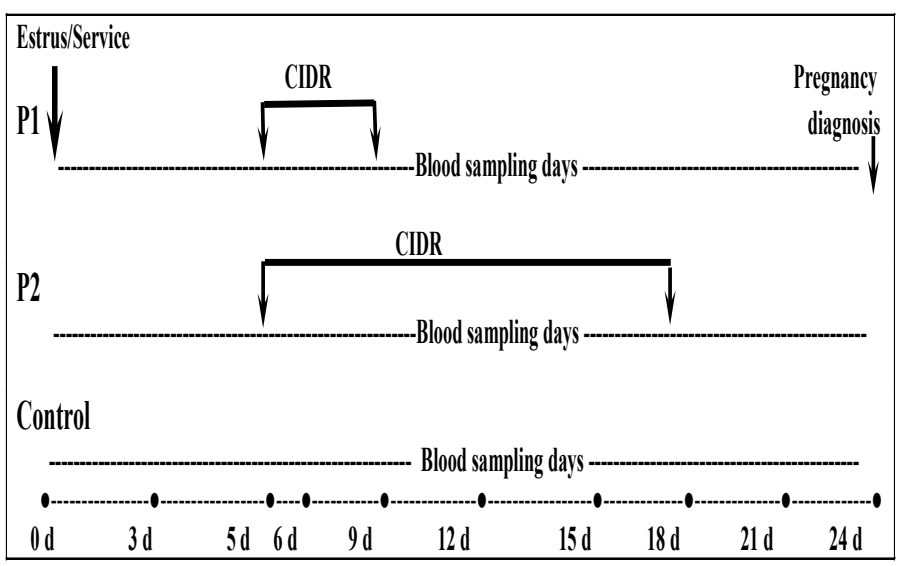

Figure 1: Diagram of the experimental design

\section{BLOOD SAMPLES AND PROGESTERONE ASSAY}

From the jugular vein of the experimental animals, blood samples were taken into clean test tubes without anticoagulants, left to clot, centrifuged (3000 rpm for $15 \mathrm{~min}$ ) for serum collection which was stored in vials at $-20^{\circ} \mathrm{C}$ until progesterone $\left(\mathrm{P}_{4}\right)$ determination. The concentration of $\mathrm{P}_{4}$ was determined in blood serum using ready antibody coated tubes kit (Diagnosis Systems Laboratories Texas, USA) by direct Radioimmunoassay technique (RIA) after the methods of the procedures outlined by the manufacturer. A sensitivity of $0.073 \mathrm{ng} / \mathrm{ml}$, and the inter- and intra-assay coefficients of variation, being 6.66 and $8.98 \%$, respectively were recorded for $\mathrm{P}_{4}$ assay. The standard curve of $\mathrm{P}_{4}$ ranged from 0.1 to $30 \mathrm{ng} / \mathrm{ml}$.

\section{DIAGNOSIS OF PREGNANCY}

After 24 days of mating each animals' pregnancy was ultrasonographically diagnosed (Digital ultrasonic diagnostic imaging System, Model Dp-30 Vet. 50/60 HZ, SHENZHEN, MINDRAY BIO-MEDICAL.ELECTRONICS, CO. LTD) using 7.5 MHz Linear array transducer at a depth of $4.3 \mathrm{~cm}$. On day 45-55 post-mating, pregnancy was rectally palpated to insure non-returned to estrus animals, then pregnancy rate was computed.

\section{STATISTICAL ANALYSis}

To test the differences in $\mathrm{P}_{4}$ concentration among groups (protocol 1, protocol 2 and control), one way-ANOVA design was applied by using software package SAS program (SAS, 2004). The differences in $\mathrm{P}_{4}$ concentration between pregnant and non-pregnant animals were determined by T-test student analysis. The significant differences among groups were performed by Duncan Multiple Rang test (Duncan, 1955) at $P<0.05$. within SAS program. Pregnancy rate of buffaloes was compared using $\chi 2$ test.

\section{RESULTS}

\section{Pregnancy rate}

In the current study, results in Table 2 revealed that pregnancy rate (PR) of cows, heifers, or as overall was higher $(\mathrm{P}<0.05)$ in both CIDR groups than control, but $\mathrm{PR}$ was higher $(\mathrm{P}<0.05)$ in protocol $2(\mathrm{P} 2)$ than in protocol $1(\mathrm{P} 1)$. Pregnancy rate was higher $(\mathrm{P}<0.05)$ for cows than heifers, regardless of treatment (Table 2).

\section{OVERALl $\mathbf{P}_{4}$ PROFILE DURING POST-MATING PERIOD}

\section{CIDR TREATMENTS VS. CONTROLS}

Results of $\mathrm{P}_{4}$ profile at estrus and different post-mating days revealed insignificant differences in $\mathrm{P}_{4}$ concentration between CIDR groups and controls on Day 0 and 3 post-mating (before CIDR treatment). Concentration of $\mathrm{P}_{4}$ in $\mathrm{P} 1$ and $\mathrm{P} 2$ was higher $(P<0.05)$ than in the control group, following CIDR incursion for both protocols, on Days 6, 9 and 12 post-mating. From Day 15 up to 24 post-mating, $\mathrm{P}_{4}$ concentration markedly increased $(P<$ $0.05)$ in $\mathrm{P} 2$ than in $\mathrm{P} 1$, while the controls showed the lowest $\mathrm{P}_{4}$ values. Concentration of $\mathrm{P}_{4}$ increased $(P<0.05)$ from Day 6 to 9 post-mating in P1, and from Day 6 to 18 post-mating in $\mathrm{P} 2$, but showed insignificant change in the controls during different post-mating days (Table 3).

\section{BUfFAlO COWS VS. BUfFALO HEIFERS}

Concentration of serum $\mathrm{P}_{4}$ showed similar trend of change in cows and heifers from estrus up to Day 24 post-mating. 
Table 2: Effect of CIDR treatment on pregnancy rate of repeat breeder buffalo cows and heifers.

$\begin{array}{lllll}\text { Item } & \mathbf{P 1}(\boldsymbol{n}=\mathbf{1 5}) & \mathbf{P 2}(\boldsymbol{n}=\mathbf{1 5}) & \text { Control }(\boldsymbol{n = 1 5}) & \text { Total } \\ \text { Buffalo cows }(\mathrm{n}=30) & 5 / 10(50 \%)^{\mathrm{b}} & 7 / 10(70 \%)^{\mathrm{a}} & 2 / 10(20 \%)^{\mathrm{c}} & 14 / 3046.7 \%)^{\mathrm{A}} \\ \text { Buffalo heifers }(\mathrm{n}=15) & 2 / 5(40 \%)^{\mathrm{b}} & 3 / 5(60 \%)^{\mathrm{a}} & 0 / 5(0 \%)^{\mathrm{c}} & 5 / 15(33.3 \%)^{\mathrm{B}} \\ \text { Overall }(\mathrm{n}=45) & 7 / 15(46.7 \%)^{\mathrm{b}} & 10 / 15(66.7 \%)^{\mathrm{a}} & 2 / 15(13.3 \%)^{\mathrm{c}} & 19 / 45(42.2 \%)\end{array}$

a,b,c Means with different small superscripts in the same row are significantly different $(\mathrm{P}<0.05)$

A,B Means with different capital superscripts in the same column are significantly different $(P<0.05)$

Table 3: Serum $\mathrm{P}_{4}$ concentration $(\mathrm{ng} / \mathrm{ml})$ of animals in the control and CIDR groups (P1 and P2) at estrus and successive post-mating days.

\begin{tabular}{|c|c|c|c|c|}
\hline Post-mating day & P1 $(n=15)$ & P2 $(n=15)$ & Control $(n=15)$ & $P$ value \\
\hline 0 & $0.46 \pm 0.021$ & $0.43 \pm 0.021$ & $0.46 \pm 0.021$ & $0.7696^{\mathrm{ns}}$ \\
\hline 3 & $0.55 \pm 0.019$ & $0.59 \pm 0.030$ & $0.62 \pm 0.031$ & $0.3691^{\text {ns }}$ \\
\hline 6 & $1.11 \pm 0.088^{a}$ & $1.16 \pm 0.089^{a}$ & $0.73 \pm 0.034^{b}$ & $0.0004^{*+\cdots}$ \\
\hline 9 & $1.57 \pm 0.201^{\mathrm{a}}$ & $1.43 \pm 0.120^{\mathrm{a}}$ & $0.81 \pm 0.075^{\mathrm{b}}$ & $0.0025^{* *}$ \\
\hline 12 & $1.49 \pm 0.149^{a}$ & $1.63 \pm 0.156^{\mathrm{a}}$ & $0.95 \pm 0.078^{b}$ & $0.0046^{*}$ \\
\hline 15 & $1.59 \pm 0.207^{b}$ & $2.11 \pm 0.222^{a}$ & $0.93 \pm 0.093^{c}$ & $0.0008^{+*+}$ \\
\hline 18 & $1.72 \pm 0.288^{b}$ & $2.66 \pm 0.034^{a}$ & $0.89 \pm 0.127^{c}$ & $0.0006^{\prime *+}$ \\
\hline 21 & $1.78 \pm 0.318^{b}$ & $2.52 \pm 0.332^{\mathrm{a}}$ & $0.94 \pm 0.151^{\mathrm{c}}$ & $0.0027^{* *}$ \\
\hline 24 & $1.95 \pm 0.371^{\mathrm{b}}$ & $2.63 \pm 0.373^{\mathrm{a}}$ & $0.73 \pm 0.219^{c}$ & $0.0016^{* *}$ \\
\hline
\end{tabular}

${ }^{a-c}$ Means with different superscripts in the same row are significantly different $P<0.05$. ns: not significant; ${ }^{* *}$ : significant at $\mathrm{P}<0.01 ;{ }^{* * *}$ :significant at $\mathrm{P}<0.001$

Concentration of $\mathrm{P}_{4}$ at estrus was higher in heifers than in cows, nearly similar on Day 3 post-mating, and higher in cows than in heifers up to Day 24 post-mating, but all differences between heifers and cows were not significant (Figure 2).

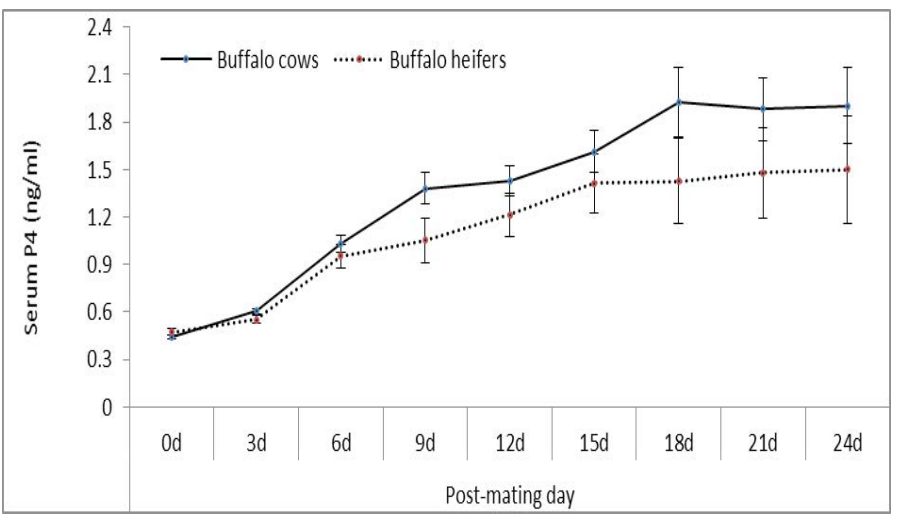

Figure 2: Changes in serum $\mathrm{P}_{4}$ concentration at estrus and successive post-mating days of buffalo cows $(n=30)$ and heifers $(n=15)$.

\section{Profile of $\mathbf{P}_{4}$ In Pregnant and non-Pregnant} ANIMALS

Concentration of $\mathrm{P}_{4}$ at estrus was lower $(P<0.01)$ in pregnant than in non-pregnant. On Day 3 post-mating the differences in $\mathrm{P}_{4}$ concentration between the pregnant and non-pregnant animals were not significant, thereafter $\mathrm{P}_{4}$ concentration increased $(P<0.001)$ in pregnant as compared to non-pregnant animals (Figure 3 ). This trend was observed between pregnant and non-pregnant animals in P1, P2 and control, as well as in cows and heifers.

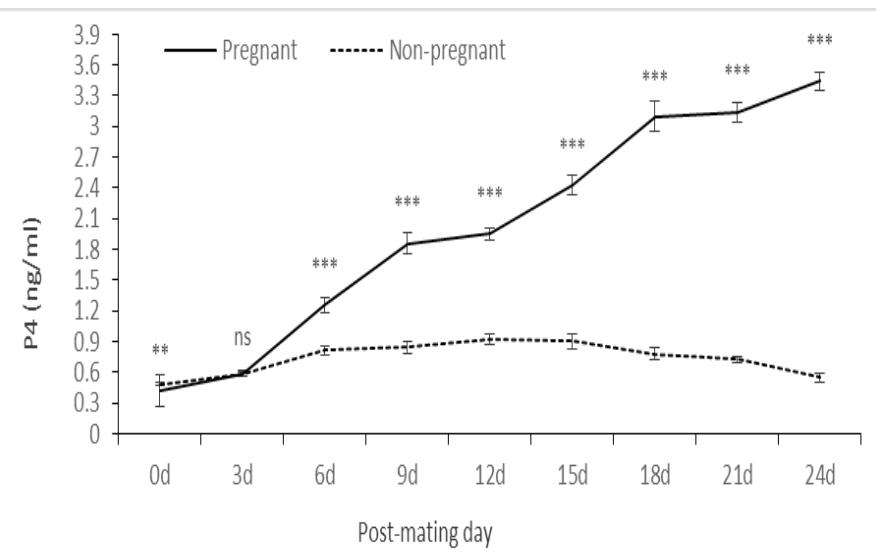

Figure 3: Serum $\mathrm{P}_{4}$ level at estrus and post-mating of pregnant $(n=19)$ and non-pregnant $(n=26)$ animals. ns: not significant; "': significant at $\mathrm{P}<0.01 ;$; : significant at $\mathrm{P}<0.001$

\section{Profile of $\mathbf{P}_{4}$ In PREgnant ANimals}

\section{CIDR TREATMENTS VS. CONTROLS}

Results in Figure 4 revealed non-significant differences in $\mathrm{P}_{4}$ concentration as affected by CIDR treatments up to Day 6 post-mating. On Day 9 up to 24 post-mating, $\mathrm{P}_{4}$ concentration was higher $(P<0.01)$ in CIDR treatments than controls, being the highest in P2 than in P1 on most post-mating days. 


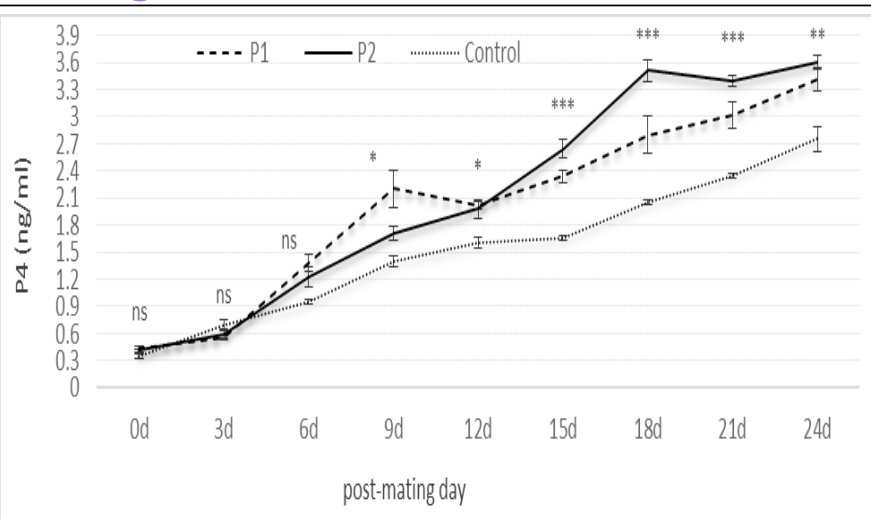

Figure 4: Serum $\mathrm{P}_{4}$ level at estrus and post-mating of pregnant animals in P1 ( $\mathrm{n}=7), \mathrm{P} 2(\mathrm{n}=10)$, and controls ( $\mathrm{n}=$ 2). ns: not significant; ": significant at $P<0.05$; "': significant at $\mathrm{P}<0.01 ;$ : significant at $\mathrm{P}<0.001$

\section{IN PREGNANT BUFFALO COWS AND HEIFERS}

The trend of change in $\mathrm{P}_{4}$ concentration on different postmating days was similar in buffaloes and heifers. On all post-mating days, $\mathrm{P}_{4}$ concentration was nearly similar at estrus and 3 days post-mating, and higher $(P \geq 0.05)$ in buffaloes compared with heifers on other post-mating days (Figure 5).

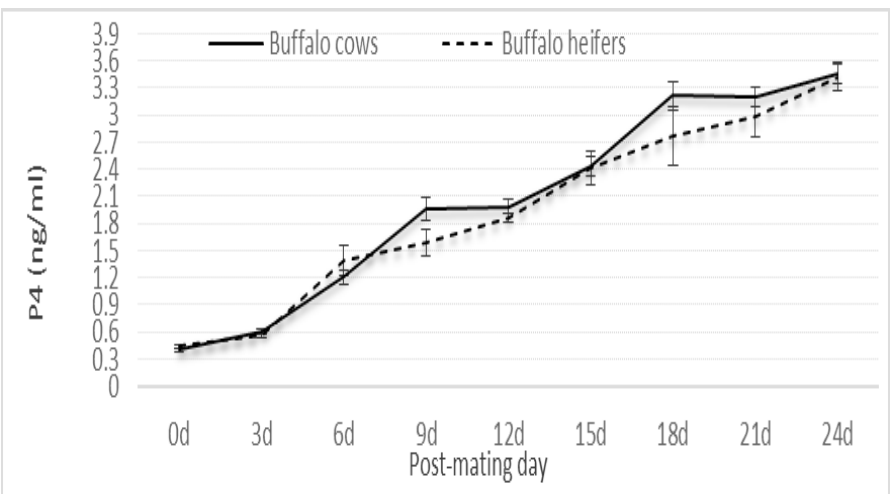

Figure 5: Serum $\mathrm{P}_{4}$ level at estrus and post-mating of pregnant cows $(n=14)$ and heifers $(n=5)$.

\section{DISCUSSION}

The current study aimed to improve pregnancy rate of repeat-breeder Egyptian buffaloes by using CIDR treatment at different intervals post-mating. In repeat breeder dairy-cows, various CIDR protocols could be used to improve pregnancy rate (Ghasemzaeh-Nava et al., 2007) and improve the fertility of repeat breeder Iraqi buffaloes (Azawi et al., 2012). To avoid long calving intervals, culling rate, and decrease of milk production due to subjecting buffaloes to $\geq 3$ services/animal, animals in our study were administrated with supplemental $\mathrm{P}_{4}$ (CIDR) at two different intervals post-mating of P1 (day 5-9) and P2 (day 5-18) in repeat breeder buffalo cows and heifers. In our study, all experimental buffalo cows were without reproductive disorders (dystocia, retained placenta, endometritis) at the previous season, and buffalo heifers were healthy with proper LBW and cyclic, but all experimental animals failed to conceived after three conductive mating cases.

In our study, we improved overall PR of cows and heifers from 13.3\% (2/15) in repeat breeder Egyptian buffaloes to $56.7 \%(17 / 30)$, being higher $(\mathrm{P}<0.05)$ in $\mathrm{P} 2$ than $\mathrm{P} 1(66.7$ vs. $46.7 \%)$ and in cows than heifers (46.7 vs. $33.3 \%)$. In bovine, Mehni et al. (2012) reported that Holstein cows treated with CIDR showed greater PR as compared to untreated animals (56 vs. $25 \%$ ). Also, CIDR treatment improved PR of dairy cattle from 35 to $48 \%$ (Sandra et al. 2007). CIDR treatment on Day 5-12 after insemination was an effective method to improve fertility in repeat breeder cows (Reza et al., 2012). Contrary, Shams-Esfanabad and Shirazi (2006) found that CIDR incursion from 5-19 days after insemination did not improve PR of repeat-breeder cows. In another way, Abo-Farw et al. (2016) in Egyptian buffalo heifers and Attoo et al. (2013) in Indian buffaloes found that PR significantly improved when animals were treated with $\mathrm{GnRH}$ on 13-day post-mating as compared to those treated on 0 or 11-day post-mating. PR significantly increased in buffaloes treated with CIDR as compared to controls (40 vs. 0\%, Azawi et al., 2012).

In domestic animals, the formation of complete CL with capacity of progesterone secretion is indicator of early pregnancy (Bulman and Lamming, 1978). Increasing $\mathrm{P}_{4}$ level improve the ability of interferon- $\tau$ (IFN) production for pregnancy regulation (Binelli et al., 2001). Also, $\mathrm{P}_{4}$ was reported to suppress the apoptosis in the luteal cells of bovine (Okuda et al., 2004). These findings indicated the possibility of PR improvement by increasing plasma $\mathrm{P}_{4}$ concentrations (Bó et al., 2002). In this respect, Van Cleeff et al. (1996) suggested that increasing $\mathrm{P}_{4}$ concentration could overcome the insensitivity of $\mathrm{P}_{4}$ receptors which may lead to increased PR. In accordance with improving PR in CIDR protocols, Mehni et al. (2012) found that the mean $\mathrm{P}_{4}$ concentration in dairy cattle after CIDR insertion (Day 5-19 after AI) was higher than untreated group. It is of interest to note that $\mathrm{P}_{4}$ concentration of both buffalo cows and heifers was $\geq 1 \mathrm{ng} / \mathrm{ml}$ in $\mathrm{P} 1$ and $\mathrm{P} 2$ on day 6 post-mating (after CIDR insertion). However, $\mathrm{P}_{4}$ level was $<1 \mathrm{ng} / \mathrm{ml}$ in control buffaloes. Colazo et al. (2004) and Muth-Spurlock et al. (2016) mentioned that the surge release of $\mathrm{LH}$ and estrus incidence need blood $\mathrm{P}_{4}$ concentration of $\geq 1 \mathrm{ng} / \mathrm{ml}$ to avoid the inhibitory mechanism of CIDR device administration. In similarity with the present study, Sandra et al. (2007) observed that the circulating $\mathrm{P}_{4}$ concentrations increased by $0.7 \mathrm{ng} \mathrm{ml}$ in CIDR treatment after $\mathrm{AI}$ in comparing the controls.

Many authors suggested that the rise of post-mating $\mathrm{P}_{4}$ level also by $\mathrm{GnRH}$, leads to improved PR. In this context, 
$\mathrm{GnRH}$ analogue injection on day 13 post-mating in repeat breeder buffalo cows (Abo-Farw and Ghoneim, 2017) may stimulate the transformation of follicular cells to luteal cells, which was required at least 2 to 3 days for optimum $\mathrm{P}_{4}$ production (Stevenson et al., 1993). Also, Nussara et al. (2008) indicated that the administration of exogenous $\mathrm{GnRH}$ in luteal phase post inseminations in dairy cattle resulted in increased serum $\mathrm{P}_{4}$ concentration. This might be beneficial in reducing early embryonic mortality especially in infertile or heat-stressed or repeat breeding cows which might have less $\mathrm{P}_{4}$ concentration after insemination. These findings may indicate the positive effect of CIDR on elevating $\mathrm{P}_{4}$ level in CIDR treatment groups as compared to control ones on different post-mating days. In this respect, Chacher et al. (2017) found an association of blood $\mathrm{P}_{4}$ concentration with conception rate in lactating cows and heifers. In our study, $\mathrm{P}_{4}$ level increased in cows than in heifers on different post-mating days, regardless of CIDR treatment, but the differences in $\mathrm{P}_{4}$ between cows and heifers were not significant. In this way, Takkar et al. (1982) found that the mean $\mathrm{P}_{4}$ concentration of different days of the cycle did not differ significantly between heifers and cows.

In accordance with the $\mathrm{P}_{4}$ profile on post-mating days for pregnant and non-pregnant animals in our study, AboFarw and Ghoneim (2017) reported that overall mean of $\mathrm{P}_{4}$ concentration on Day 23 and 25 post-mating was lower in non-pregnant $(0.785 \pm 0.158$ and $1.314 \pm 0.123 \mathrm{ng} / \mathrm{ml})$ than in pregnant $(6.679 \pm 0.218$ and $6.381 \pm 0.247 \mathrm{ng} / \mathrm{ml})$ buffaloes. Also, Raj et al. (2016) recorded a greater number of buffaloes became pregnant when $\mathrm{P}_{4}$ concentrations at the time of $\mathrm{AI}$ was below the suprabasal level and the pregnancy reduced when the $\mathrm{P}_{4}$ level is between suprabasal and $1 \mathrm{ng} / \mathrm{ml}$. None of the cows become pregnant when the $\mathrm{P}_{4}$ level was more than $1 \mathrm{ng} / \mathrm{ml}$. Mean values of serum $\mathrm{P}_{4}$ at estrus were $0.895 \pm 0.134 \mathrm{ng} / \mathrm{ml}$ in pregnant and $1.429 \pm 0.235 \mathrm{ng} / \mathrm{ml}$ in non-pregnant buffaloes. The lowest $\mathrm{PR}$ and $\mathrm{P}_{4}$ of controls presented in this study, particularly for buffalo-heifers, may suggest that increased serum $\mathrm{P}_{4}$ level may rise the $\mathrm{PR}$, regardless of CIDR treatment (Mehni et al., 2012). Our results indicated that PR was positively affected by CIDR-treatments having the greatest effect on $\mathrm{P}_{4}$ level on different post-mating days. The CIDR treatment markedly affects serum $\mathrm{P}_{4}$ level and $\mathrm{PR}$, whereas the administration of CIDR during days post-mating (day 5) increased serum $P_{4}$ level in buffalo cows and heifers.

Generally, $\mathrm{P}_{4}$ is an essential hormone in the maintenance of pregnancy in cows. The higher $\mathrm{P}_{4}$ levels in the early pregnancy are related to the embryonic development and increase in interferon- $\tau$ production and PR (Beltman et al., 2009). Animals on day 5, with higher plasma $\mathrm{P}_{4}$ concentrations, had developmentally more advanced and viable embryos (Green et al., 2010). In this context, Leyan et al. (2013) indicated that the benefit of $\mathrm{P}_{4}$ supplementation on the fertility of cows required exogenous $\mathrm{P}_{4}$ supplementation to start between day 3-7 and the appropriate reproductive status of the treated cows. These findings support the observed higher $\mathrm{P}_{4}$ level after CIDR insertion in pregnant than non-pregnant in P1 and P2 in comparing with control, being higher in $\mathrm{P} 2$ than in $\mathrm{P} 1$. Also, $\mathrm{P}_{4}$ level was higher in pregnant animals in $\mathrm{P} 2$ than in $\mathrm{P} 1$, being higher than in pregnant control animals. In our study CIDR insertion from Day 5 to 9 post-mating resulted in lower PR than in those treated with CIDR (Day 5-18). However, CIDR treatment on day 5 until 12 after insemination was effective method to improve fertility in repeat breeder cows due to a direct effect of $\mathrm{P}_{4}$ on fetal development (Reza et al., 2012) and embryo viability (Leroy et al., 2008). The CIDR device improved PR by reducing embryonic losses in dairy heifers (Alnimer, 2009).

Generally, results of this study support the hypothesis that a CIDR device when properly used, on Day 5 to 18 postmating increased $\mathrm{P}_{4}$ level in the majority of repeat breeder buffaloes within few days after CIDR removal and reduced embryonic losses. Green et al. (2010) discussed the positive effects of $\mathrm{P}_{4}$ on reducing embryonic mortality, stating that $\mathrm{P}_{4}$ concentration on Day 4 and 5 has a positive correlation with interferon-tau (IFN-s) production on Day 16 postAI. Similarly, Mann and Lamming (2006) reported that $\mathrm{P}_{4}$ treatment at the interval from Day 5 to 9 post-AI increased the production of IFN-s by the embryo. Finally, Leroy et al. (2008) mentioned that early embryonic life is incapable of sub-optimal uterine micro-environment and inadequate CL function with reduced $\mathrm{P}_{4}$.

\section{CONCLUSION}

According to the obtained results, CIDR treatment of repeat breeder buffaloes on day 5 post-mating that was removed on day $9(\mathrm{P} 1)$ or on day $18(\mathrm{P} 2)$ had benefited from progesterone supplementation for improvement of pregnancy. However, long $\mathrm{P}_{4}$ treatment $(\mathrm{P} 2)$ is concluded for buffaloes suffering from low $\mathrm{P}_{4}$ level at the early pregnancy stage and repeat breeding. Increasing $\mathrm{P}_{4}$ level by CIDR treatment from 5-18 days post-mating could be recommended as a useful strategy to reduce the embryonic mortality and improving pregnancy of repeat breeder buffalo cows and heifers.

\section{CONFLICT OF INTEREST}

There are no conflict of interests of this manuscript.

\section{AUTHOR CONTRIBUTIONS}

Aim and design of the manuscript (A.E. Abdel-Khalek 
and M.A. Abo-Farw), acquisition of data (M.A. AboFarw and W. M. Nagy), statistical analyses of data (A.E. Abdel-Khalek and M.A. Abo-Farw), statistical analyses (M.A. Abo-Farw and A.E. Abdel-Khalek), drafting the manuscript (M.A. Abo-Farw, A.E. Abdel-Khalek and W.M. Nagy), revision of the manuscript (A.E. Abdel-Khalek and M. A. Abo- Farw), and preparing the manuscript for publication (all authors).

\section{REFERENCES}

-Abo-Farw MA, El-Harairy MA, Abdel-Khalek AE, Darwish SA (2009). Physiological studies on repeat breeder buffalo heifers. Ph. D. Thesis, Fac. of Agric., Mansoura University, Cairo,Egypt.https://doi.org/10.21608/jappmu.2019.59995.

-Abo-Farw MA, Ghoneim MM (2017). Effect Of GnRH Administration At Mating And During Luteal Phase On Pregnancy Rate Of Repeat Breeder Buffalo Cows. Vet. Med. J. - Giza. (VMJG) 63 (1): 65 - 74.

-Abo-Farw MA, El-Ratel IT, Abdel-Khalek AE, Abouelghet HA, Ghoneim MM (2016). Effect of GnRH treatment during different times post-mating on pregnancy rate of buffalo heifers. Egyptian Journal Animal Prod. 53(2): 5964. Issued by The Egyptian Society of Animal Production. https://www.researchgate.net/scientific-contributions/AboFarw-2117294272.

- Abo-Farw MA, Gabr SHA, Nagy WM, EL- Fateh Hammad M, EL-Emary EAA (2019). Synchronization of Estrus and Ovulation using CIDR and Prostaglandin for Improving Pregnancy Rate of Repeat Breeder Egyptian Buffaloes. J. Anim. Poult. Prod., Mansoura Univ., 10(9): 261 - 268. https://doi.org/10.21608/jappmu.2019.59995.

-Ahmad M, Ahmad N, Ahmad I, Akhtar N, Ali S (2004). Racing stress and conception rate in repeat breeding buffaloes and cows. Pakistan Vet. J. 24(4). https://www.researchgate.net/ publication/26522152.

-Alnimer MA (2009). The effect of a progesterone $\left(\mathrm{P}_{4}\right)$ intravaginal device (CIDR) on resynchronisation of oestrus and embryonic loss in previously timed inseminated dairy heifers. Animal. 3: 1271-1278. https://doi.org/10. 1017/ S1751731109004832

-AOAC (2000). Official Methods of Analysis 17th Ed. Association of Analytical Chemists. https://www. worldcat.org/title/official-methods-of-analysis-of-aoacinternational/oclc/44761301.

-Attoo MZ, Prasad LS, Gupta HP, Hussain A (2013). Effect of Post-Mating GnRH Treatment on Serum Progesterone Profile and Conception Rate in Buffaloes. Iranian J. Appl.. Anim. Sci. 3(1): 83-90. https://scholar.google.com.eg/ scholar?q.

-Azawi OI, Delpli OS, Ali M, Ahmed Al, Hadad AS, Jamil MS, Hussien AS A (2012). Treatment of repeat breeding of Iraqi buffaloes using different CIDR protocols. Iranian Journal of Applied Animal Science, 2(3): 247-250. http://ijas.iaurasht. ac.ir/article_514321.html.

-Azawi OI, Omran SN, Hadad JJ (2008). A study on repeat breeding of Iraqi buffalo cows. Buffalo Bull. 27:274-283. https://www.scopus.com/record/display.uri?eid.

-Beltman EM, Lonergan P, Dıskın GM, Roche FJ, Crowe AM (2009). Effect of progesterone supplementation in the first week post conception on embryo survival in beef heifers.
Journal of Animal Health and Production Theriogenology.71(7):1173-1179. https://doi.org/10.1016/

- Binelli M, Thatcher WW, Mattos R, Baruselli PS (2001). Antiluteolytic strategies to improve fertility in cattle. Theriogenology. 56:1451-1463. https://doi.org/10.1016/ s0093-691x(01)00646-x.

-Bó GA, Baruselli PS, Moreno D, Cutaia L, Caccia M, Tríbulo R, Tríbulo H, Mapletoft RJ (2002). The control of follicular wave development for self-appointed embryo transfer programs in cattle. Theriogenology, 57(1):53-72. https://doi. org/10.1016/S0093-691X(01)00657-4.

-Bulman, D.C., Lamming, G.E., 1978. Milk progesterone levels in relation to conception, repeat breeding and influencing acyclicity in dairy cows. J. Reprod. Fertil., 54:447-458. https://doi.org/10.1530/jrf.0.0540447.

- Chacher MFA, Armağan O, Armağan H (2017). Efficacy of repeatedly used CIDR device in cattle reproduction: a metaanalysis review of progesterone concentration and conception rate. Turk. J. Vet. Anim. Sci. 41(5): 692-697. https://doi.org/10.3906/vet-1706-75.

- Chebel RC, Al-Hassan MJ, Fricke PM, Santos JEP, Lima JR, Martel CA, Stevenson JS, Garcia R, Ax RL (2010). Supplementation of progesterone via controlled internal drug release inserts during ovulation synchronization protocols in lactating dairy cows. J. Dairy Sci. 93: 922-931. https://doi.org/10.3168/jds.2009-2301.

- Colazo MG, Kastelic JP, Whittaker PR, Gavaga QA, Wilde R, Mapletoft RJ (2004). Fertility in beef cattle given a new or previously used CIDR insert and estradiol, with or without Progesterone. Anim. Reprod. Sci.; 81(1-2): 25-34. https:// doi.org/10.1016/j.anireprosci.2003.09.003.

- Campanile G, Neglia, G., Gasparrini, B, Galiero G, Prandi A, Di Palo R, D’Occhio MJ, Zicarelli L (2005). Embryonic mortality in buffaloes synchronized and mated by AI during the seasonal decline in reproductive function. Theriogenology. 63: 2334-2340. https://doi.org/10.1016/j. theriogenology.2004.10.012.

-Duncan DB (1955). Multiple range and multiple F test. Biometrics. 11: 1-42. https://doi.org/10.2307/3001478.

-El-Khadrawy HH, Ahmed W, Emtenan M, Hanafi M (2011). Observation on repeat breeding in farm animals with emphasis on its control. Journal of reproduction and infertility 2(1): 1-7.

- Gaja AO, Katsumi H, Chikara K, Toshiyuki K(2008). Evaluation of the effect of a $3 \mathrm{rd} \mathrm{GnRH}$ injection administered six days after the 2nd GnRH injection of Ovsynch on the reproductive performance of Japanese black cows. J. Vet. Sci., 9(3), 273-279. https://doi.org/10.4142/jvs.2008.9.3.273.

-Ghasemzaeh-Nava H, Kohsari, H, Tajik P (2007). Maintenance of pregnancy in repeat breeder dairy cows by CIDR administration after breeding. Pakistan J. Biolog. Sci. 10 (14): 2402-2406. ISSN 1028-8880. https://doi.org/10.3923/ pjbs.2007.2402.2406.

- Green JC, Okamura CS, Poock SE, Lucy MC (2010). Measurement of interferon-tau (IFN-s) stimulated gene expression in blood leukocytes for pregnancy diagnosis within 18-20 d after insemination in dairy cattle. Anim. Reprod. Sci. 121, 24-33. https://doi.org/10.1016/ j.anireprosci. 2010.05.010.

- Karen A, Árpád Csaba B, Rosa M, Rezső K, NoelitaMelo D, Jean-François B, János T, István M, Ottó S (2014). Relationship of Progesterone, Bovine Pregnancy-Associated Glycoprotein-1 and Nitric Oxide with Late Embryonic and Early Fetal Mortalities in Dairy Cows. J. Reprod. Develop. 
60(2). https://doi.org/10.1262/jrd.2013-033.

-Kastelic JP (1994). Non-infectious embryonic loss in cattle. Vet. Med. 89(6): 584-589.

- Leroy JL, Opsomer MR, Van Soom GA, Goovaerts IGF, Bols PEJ (2008). Reduced fertility in high-yielding dairy cows: are the oocyte and embryo in danger? Part I: the importance of negative energy balance and altered corpus luteum function to the reduction ofoocyte and embryo quality in high-yielding dairy cows. Reprod. Domest. Anim. 43: 612622. https://doi.org/10.1111/j.1439-0531.2007.00960.x.

-Leyan Y, Robert R, Zhendan S, George M (2013). Efficacy of progesterone supplementation during early pregnancy in cows: a meta-analysis. george.mann@nottingham.ac.uk; Z.D. Shi: Tel: +86(0)25-84390956; E-mail address: zdshi@ jaas.ac.cn. https://doi.org/10.1016/ j. theriogenology. 2015.12.027.

-Lonergan P, OHara L, Forde N (2013). Role of diestrus progesterone on endometrial function and conceptus development in cattle. Anim. Reprod., 10(2): 223-227. https://animal-reproduction.org/ article/5b5a6049f7783717068b4695.

-Mann GE, Lamming GE (2006). Relationship between the maternal endocrine environment, early embryo development and the inhibition of the luteolytic mechanism in the cow. Reproduction. 121(1): 175-180. https://doi.org/10.1530/ REP.0.121,1,175.

- Mehni SB, Shabankareh HK, Kazemi-Bonchenari M. Eghbali M (2012). The Comparison of Treating Holstein Dairy Cows with Progesterone, CIDR andGnRH After Insemination on Serum Progesterone and Pregnancy Rates. Reprod. Dom. Anim., 47: 131-134. https://doi.org/10.111 1/j.1439-0531.2011.01811.

- Muth-Spurlock AM, Poole DH, Whisnant CS (2016). Comparison of pregnancy rates in beef cattle after a fixedtime AI with once-or twice-used controlled internal drug release devices. Theriogenology. 85: 447-451. https://doi. org/10.1016/j.theriogenology.2015.09.019.

- Nussara V, Arun C, Wanvipa S, Kriwon H (2008). Progesterone profiles and conception of dairy cattle administered with gonadotropin releasing hormone in luteal phase post inseminations. J. Mahanakom Vet. Med. 3(1). http://www. vet.mut.ac.th/journal_jmvm/article/3-1/5_research_3-1. pdf.

- Okuda K, Korzekwa A, Shibaya M, Murakami S, Nishimura R, Tsubouchi M, Woclawek-Potocka I, Skarzynski DJ (2004). Progesterone is a suppressor of apoptosis in bovine luteal cells. Biol. Reprod, 71: 2065-2071. https://doi.org/10.1095/ biolreprod.104.028076.

- Patel KR, Dhami AJ, Hadiya KK, Savalia KK, Killedar A, Patel SB (2014). Effect of mid-cycle PGF2 $\alpha$ and GnRH at AI on conception rates, plasma progesterone and biochemical profile in repeat breeding crossbred cows. Indian J. Field Vet., 9(3): 5-11. https://www.semanticscholar.org

- Raj MP, Naidu GV, Srinivas M, Raghunath M, Rao, KA (2016). Effect of serum progesterone levels at estrus on conception in Graded Murrah buffaloes under field conditions. Theriogenology Insight: 6(3): 127- 133. https:// doi.org/10.5958/2277-3371.2016.00018.8. Corpus ID: 90132329.

- Reza V, Alireza HS, Samad M (2012). Comparative Study of after Insemination in Use of CIDR and GnRH in fertility Rate Improvement in Repeat Breeder Cows. Research
J. Biolog. Sci. 7(5): 204-205. https://doi.org/10.3923/ rjbsci.2012.204.205.

- Rodrigues CA, Teixeira AA, Ferreira RM, Ayres H, Mancilha RF, Souza AH, Baruselli PS (2010). Effect of fixed-time embryo transfer on reproductive efficiency in high-producing repeat-breeder Holstein cows. Anim. Reprod. Sci. 118: 11017. https://doi.org/10.1016/j.anireprosci.2009.06.020.

-Stevenson JS, Phatak AP, Rettmer I, Stewart RE (1993). Postinsemination administration of receptal: Follicular dynamics, duration of cycle, hormonal responses, and pregnancy rates. J. Dairy Sci., 76: 2536-2547. https://doi.org/10.3168/jds. S0022-0302(93)77589-X.

-Sandra FL, Butler WR, Bruce Currie W (2007). Pregnancy rates in lactating dairy cattle following supplementation of progesterone after artificial insemination. Anim. Reprod. Sci. 102(1-2): 172-179. https://doi.org/10.1016/j. anireprosci.2007.02.023.

-Savalia KK, Dhami AJ, Hadiya KK, Patel KR, Sarvaiya NP (2014). Influence of controlled breeding techniques on fertility and plasma progesterone, protein and cholesterol profile in true anestrus and repeat breeding buffaloes. Vet. World, 7(9): 727- 732. https://doi.org/10.14202/ vetworld.2014.727-732.

-SAS (2004). SAS Institute Inc. SAS User's Guide, Statistics. Cary, NC.

-Shams-Esfanabad N, Shirazi A (2006). Effects of supplementation of repeat-breeder dairy cows with CIDR from 5-19 post-insemination on pregnancy rate. Pakistan J. Biol. Sci., 9 (11): 2173-2176. https://doi.org/10.3923/ pjbs.2006.2173.2176.

- Singh C (2003a). Response of anestrus rural buffaloes (Bubalusbubalis) to intravaginal progesterone implant and PGF2ā injection in summer. J. Vet. Sci., 4:137-141. https:// doi.org/10.4142/jvs.2003.4.2.137.

-Singh J, Alanda AS, Adams GP (2000). The reproductive pattern and efficiency of female buffaloes. Anim. Reprod. Sci. 61: 593-604. https://doi.org/10.1016/s0378-4320(00)00109-3.

- Singh M, Sharma A, Kumar P (2017). Repeat breeding and its treatment in dairy cattle of himachal Pradesh (INDIA). A REVIEW. Indian J. Anim. Reprod. 2017 38(2) :1-5 ref.25. https://www.researchgate.net/publication/317718138.

- Takkar OP, Singh M, Varmana PN (1982). Progesterone profile in buffaloes during various stages of oestrous cycle using radioimmunoassay technique. Theriogenology. 17(5): 565569. https://doi.org/10.1016/0093-691X(82)90182-0.

- Thatcher WW, Guzeglu A, Mattos R, Binelli M, Hansen TR, Pru JK (2001). Uterine conception interaction and reproductive failure in cattle. Theriogenology. 56; 14351450. https://doi.org/10.1016/s0093-691x(01)00645-8.

-Van Cleeff J, Macmillan KL, Drost M, Lucy MC, Thatcher, WW (1996). Effects of administering progesterone at selectedintervals after insemination of synchronized heifers on pregnancy rates and resynchronization of returns to service. Theriogenology. 46: 1117-1130. https://doi. org/10.1016/s0093-691x(96)00284-1.

-Walsh RB, LeBlanc SJ, Duffield TD, Kelton DF, Walton JS, Leslie KE (2007). Synchronization of estrus and pregnancy risk in anestrous dairy cows after treatment with a progesterone-releasing intravaginal device. J. Dairy Sci. 90: 1139-1148. https://doi.org/10.3168/jds.S00220302(07)71600-4. 